\title{
Helppoa vai vaikeaa arvioida? Yleisten kielitutkintojen suomen kielen arvioijien käsityksiä vironkielisten arvioinnista
}

\author{
SARI AHOLA, HENNA TOSSAVAINEN \\ Jyväskylän yliopisto
}

Tiivistelmä. Tarkastelemme tässä artikkelissa Yleisten kielitutkintojen suomen kielen arvioijien käsityksiä vironkielisten testiin osallistujien arvioinnin helppoudesta ja vaikeudesta. Tutkimus perustuu arvioijilta saatuihin kirjallisiin vastauksiin, jotka on analysoitu käyttämällä aineistolähtöistä sisällönanalyysia, jonka mukaisesti arvioijien vastaukset kategorisoitiin arviointia helpottaviin ja vaikeuttaviin näkemyksiin. Arviointia helpottavana asiana arvioijat pitivät vironkielisten hyviä testiteknisiä taitoja ja kykyä ymmärtää tehtävänannot sekä selkeää ääntämystä ja sujuvaa puheen ja kirjoittamisen tuottamista. Vironkieliset osasivat arvioijien mielestä valita tutkintotasonsa oikein, mikä helpottaa suoritusten sijoittamista arviointiasteikolle. Vaikeuksia arvioinnissa aiheutti erityisesti kielten samankaltaisuus. Arvioijien oli välillä vaikea määrittää kielten väliset rajat, mistä syystä arvioijat nostivat vastauksissa esiin, onko tärkein arviointikriteeri ymmärrettävyys vai onko arvioinnissa keskityttävä tunnistettaviin vironkielisiin 'virheisiin'.

Avainsanat: kielitaidon arvioinnin validius, käsitys kielitaidosta, suomi toisena ja vieraana kielenä, viron kieli 


\section{Johdanto}

Viron ja suomen kielten sukukielisyys on rikkaus, mutta myös ymmärtämisongelmien aiheuttaja ja jopa huumorin lähde. Näillä melko yleisillä käsityksillä voi olla merkitystä sille, miten viroa äidinkielenään puhuvien suomen kielen käyttöön suhtaudutaan yksityisesti, mutta niillä voi olla myös laajempia ammatillisia vaikutuksia. Syntyperäiset kielenpuhujat ovat herkkiä huomaamaan niin puheesta kuin kirjoituksestakin, että puhuja tai kirjoittaja ei ole äidinkielinen. Toivola (2011) on esimerkiksi todennut tutkiessaan vierasperäisen aksentin arviointia suomen kielessä, että vieraalla aksentilla on merkitystä sosiaalisissa tilanteissa. Sillä on merkitystä kommunikaation sujumiseen silloinkin, kun puhe on täysin ymmärrettävää. Kielellä on sosiaalista voimaa, ja se pystyy välittämään paljon muutakin kuin yksittäisiä tiedon murusia. Kuulijat voivat käsittää kielen lingvistisen ja paralingvistisen vaihtelun tuottamat erilaiset ilmentymät sekä ihmisen omaksi että sosiaaliseksi piirteeksi (Cargile ym. 2010: 61).

Kielitaidon arvioinnin alueella tunnustetaan se tosiasia, että myös arvioijilla on omat periaatteensa ja uskomuksensa, jotka voivat vaikuttaa arvioinnin taustalla (Hamp-Lyons 2000: 31). Vaikka puhumisen ja kirjoittamisen arvioinnissa pidetään tärkeänä noudattaa teoreettisesti perusteltuja ja käytännössä hyväksi koettuja arviointikriteereitä mahdollisimman tarkkaan, arviointia toteuttavat kuitenkin ihmiset ja inhimillisen elämän mukanaan tuomia käsityksiä ei subjektiivisessa arvioinnissa voida välttää. Arvioinnin luotettavuuden vaatimusten mukaan on hyvä pitäytyä tietyissä eksplisiittisissä ammatillisissa standardeissa, mutta arvioinnin validiuden ja oikeudenmukaisuuden näkökulmasta myös pyrkiä tuomaan esiin sellaiset käsitykset, jotka implisiittisesti kulkevat arvioijien mukana ja saattavat vaikuttaa arvioinnin lopputulokseen. Kysymykseen tulevat sellaiset testin konstruktiin alun perin kuulumattomat muuttujat, jotka saattavat aiheuttaa testitulosten kontrolloimatonta vaihtelua. (Fulcher \& Davidson 2010: 254, 270.) 
Arviointitilanteessa arvioijat usein tunnistavat kielenkäyttäjän taustalta löytyvän ensikielen, joka voi herättää erilaisia käsityksiä kielenpuhujasta ja odotuksia hänen selviytymisestään kielellisissä tilanteissa. Kyse on ns. sädekehävaikutuksesta, jolloin arvioija kiinnittää arviointiasteikon sijaan huomioita myös muihin tekijöihin, joita ohjaavat hänen omat henkilökohtaiset mieltymyksensä tai arvotuksensa (esim. Tarnanen 2014). Näiden käsitysten ja odotusten tunnistaminen on tärkeää myös arvioijalle itselleen, sillä oman arvioinnin reflektointi tuo varmuutta ja luotettavuutta arviointitilanteeseen. Erityisesti suurten testijärjestelmien tutkinnoissa, joissa testituloksilla on huomattavaa merkitystä arvioitavan elämälle (ns. high-stakes assessment), on tärkeää, että arvioijat mieltävät laatukriteerit tarpeeksi samansuuntaisina, jotta arviointi olisi mahdollisimman yhdenmukaista (esim. Attali 2016: 99).

Tarkastelemme tässä artikkelissa Yleisten kielitutkintojen suomen kielen arvioijina $(\mathrm{n}=27)$ toimivien käsityksiä siitä, mikä arvioinnissa on vaikeaa ja mikä helppoa silloin, kun arvioitavana ovat vironkieliset osallistujat. Yleisten kielitutkintojen suoritusten arviointia ohjaa kuusiportainen kielitaidon kehittymistä kuvaava asteikko, joka on linkitetty Eurooppalaiseen viitekehykseen. Vaikka arviointi on kriteeriviitteistä ja arvioinnissa pyritään koulutusten ja arvioijien toiminnan seuraamisen kautta yhdenmukaiseen käsitykseen taidosta, arvioijat toimivat kuitenkin yksilöinä, jolloin arvioinnissa ei voida välttyä heidän yksilöllisten käsitystensä vaikutuksista. Arvioinnin taustalla vaikuttavat muun muassa ns. kannatetun tiedon (esim. Osterman \& Kottkamp 2004) eli tiedostetun ja opitun tiedon lisäksi arvioijan persoonalliset toimintatavat. Persoonallisiin toimintatapoihin lukeutuvat henkilökohtaiset kokemukset, käsitykset ja yleiset uskomukset sekä toisten ihmisten kokemukset. Näin syntyneet käsitykset ovat usein pitkällisen kulttuurikehityksen ja sosiaalisen oppimisen kautta omaksuttuja tietoja ja arvoja. Arvioijien käsitysten tutkiminen on tärkeä osa arvioinnin luotettavuuden ja validiuden laadullista seurantaa. Yleisten kielitutkintojen kaltaisessa testijärjestelmässä, jossa osallistujilla on varsin erilaiset taustamuuttujat, arvioijien käsitysten tutkiminen liittyy oleellisena osana tutkintojen jatkuvan kehittämisen periaatteeseen. 


\section{Tutkimusaineisto ja tutkimusmenetelmä}

Artikkelissa käytettävä aineisto perustuu Yleisten kielitutkintojen suomen kielen arvioijien vastauksiin vironkielisten testiin osallistujien arviointiin liittyvistä helppouksista ja vaikeuksista. Artikkelin tutkimusaineisto kerättiin syksyllä 2015 kyselyn avulla. Kysely lähetettiin 30 kokeneelle Yleisten kielitutkintojen arvioijalle, joiden tiedettiin varmasti arvioineen vironkielisten osallistujien suorituksia kirjoittamisen ja puhumisen osakokeessa. Näillä arvioijilla on myös ollut useiden vuosien kokemus suomi toisena ja vieraana kielenä opettamisesta. Arvioijia pyydettiin vastaamaan lyhyesti seuraaviin kysymyksiin:

1. Mikä on helppoa vironkielisten puhumisen/kirjoittamisen arvioinnissa?

2. Mikä on vaikeaa vironkielisten puhumisen/kirjoittamisen arvioinnissa?

Kyselyyn vastasi 27 arvioijaa, joiden vastaukset kerättiin yhteen ja analysoitiin sisällönanalyysin avulla. Sisällönanalyysi on sanallista sisällön kuvaamista, jossa tutkittavia tekstejä analysoidaan merkityksiä tuottavina. Jos analysoitavat tekstit ovat lyhyitä, niiden lukeminen ja tulkinta pyritään tekemään syvällisesti. (Tuomi \& Sarajärvi 2009.) Sisällönanalyysissa aineistoa tarkastellaan tekstiin sisältyvien ilmaisujen ja sanojen perusteella ja niiden pohjalta luodaan merkityksiä, synteesejä ja johtopäätöksiä. Tulkinnallisuus liittyy sisällönanalyysiin ja tulkinnan kautta saadut merkitykset ovat aina tutkijoiden omiin näkemyksiin perustuvia havaintoja. (Grönfors 1982.)

Sisällönanalyysia voidaan tehdä laadullisesti aineistosta niin aineistolähtöisesti, teoriaohjaavasti kuin teorialähtöisestikin (Tuomi \& Sarajärvi 2009). Tutkimuksellisena lähtökohtana tässä tutkimuksessa on teoriaohjaava sisällönanalyysi, jossa analyysiin vaikuttavat taustalla olemassa oleva tutkimustieto sekä teoriat arvioinnista ja kielitaitokäsityksistä; analyysin lähtökohtana on kuitenkin arvioijilta kerätty kirjallinen aineisto. Arvioijien kirjoitetuista vastauksista eriteltiin samankaltaiset, mutta myös toisistaan eroavat käsitykset, jotka sitten kategorisoitiin ja 
luokiteltiin sisällön perusteella. Näin syntyneiden luokkien perusteella voitiin tehdä vironkielisten arviointiin liittyvistä helpoista ja vaikeista asioista päätelmiä ja kuvauksia aiempaan tutkimustietoon tukeutuen. (Tuomi \& Sarajärvi 2009.)

\section{Yleisten kielitutkintojen suomen kielen tutkinto}

Yleiset kielitutkinnot (YKI) on kansallinen lakiin ja asetuksiin perustuva toisen ja vieraan kielen testijärjestelmä, jossa tutkintoja tarjotaan yhdeksässä eri kielessä. Suomen kielen tutkinto on tutkintojärjestelmän suosituin tutkintokieli, sillä vuodesta 2003 Suomen kansalaisuuden edellytyksenä olevan kielitaitovaatimuksen (suomi tai ruotsi) on voinut osoittaa suorittamalla Yleisten kielitutkintojen keskitason tutkinnon. Tutkinto on siis monelle osallistujalle portti suomalaiseen yhteiskuntaan ja työelämään ja sikäli tutkinnon tulos on osallistujille merkityksellinen. Tutkintojärjestelmän alkuajoista - vuodesta 1994 - lähtien tutkinnot on rakennettu siten, että niiden suorittaminen ei ole sidottu mihinkään opetussuunnitelmaan tai -ohjelmaan, vaan niitä ohjaa Yleisten kielitutkintojen perusteet (viimeisin vuodelta 2011), joissa tutkintojen rakenne ja sisällöt määritellään. Vuodesta 2003 tutkinto on ollut linkitettynä Eurooppalaiseen viitekehykseen (EVK), jonka kuusiportaiseen taitotasoasteikkoon rakentuvat suurelta osin myös tutkintojärjestelmässä käytettävät arviointikriteerit.

\section{Arvioijana toimiminen Yleisissä kielitutkinnoissa}

Yleisten kielitutkintojen arvioijana voi toimia vain henkilö, joka on merkitty Opetushallituksen ylläpitämään arvioijarekisteriin. Arvioijaksi edetään käymällä Jyväskylän yliopiston Soveltavan kielentutkimuksen keskuksen tarjoama arvioijakoulutus, johon osallistuvalta edellytetään maisteritason opintoja suomen kielestä, nykyisin mieluiten S2-suuntautuneita. Arvioijalta edellytetään myös kokemusta S2-opettajana toimimisesta. Useilla arvioijiksi kouluttautuneilla opettajilla on taustallaan 
suomen sukukielten opintoja, koska ne kuuluvat suomen maisteritason opintoihin. Näin ollen arvioijat ovat yleensä suorittaneet ainakin viron kielen alkeisopinnot, jotkut jopa perehtyneet kieleen syvemmin. On mahdollista sanoa, että viron ja suomen kielen erot ja yhtäläisyydet ovat arvioijille jonkin verran tuttuja, samoin kuin esimerkiksi tyypilliset virolaisten suomen kielen käyttäjien ääntämistavat.

Arvioijaoikeuden saamisen jälkeen arvioijalta edellytetään osallistumista tutkintojen arviointitilaisuuksiin ja niitä edeltäviin arviointikoulutuksiin. Tällä arvioijakoulutuksella pyritään sekä arvioijien väliseen yhdenmukaisuuteen että yksittäisten arvioijien johdonmukaisuuteen arviointikriteerien tulkinnassa. Arvioijan toiminta kansallisessa kielitutkinnossa ei ole vain arvioijan itsensä toiminnan varassa, vaan myös testijärjestelmän vastuulla, joten testijärjestelmällä on käytössään erilaisia tilastollisia menetelmiä arvioijan johdonmukaisuuden ja yhdenmukaisuuden tarkastelemiseksi. Johdonmukaisuutta voidaan tarkastella paitsi arvioijan sisäisenä myös arvioijien keskinäisenä toimintana. Myös arvioijien ankaruutta ja lempeyttä voidaan seurata tilastollisesti. (Ks. Tossavainen \& Ahola 2014.)

Koulutusta pidetään tärkeänä osana arvioijien toimintaa, koska se mahdollistaa avoimen keskustelun arviointikriteereistä ja niiden tulkinnasta sekä antaa tietoa yksittäisten arvioijien käsityksistä. Kirjoittamisen ja puhumisen arviointi on subjektiivista toimintaa, ja samasta suorituksesta saattavat eri arvioijat antaa eri arvosanan. Koulutuksella voidaan jonkin verran vaikuttaa arvioijien tulosten yhtenäisyyteen, mutta varsinaisessa arvioinnissa arvioija on käsityksineen yksin, joten yksittäisen arvioijan näkemykset ja käsitykset ovat tärkeitä tarkasteltavia testiarviointien yhteydessä. (Fulcher \& Davidson 2010.)

\section{Virolaiset osallistujat Yleisissä kielitutkinnoissa}

Tutkintoon osallistuneista saadaan tietoa ennen tutkintoa täytettävän taustatietolomakkeen avulla. Lomakkeen täyttäminen on vapaaehtoista, mutta esimerkiksi $92 \%$ virolaisista osallistujista täytti lomakkeen 
tutkintoon ilmoittautumisen yhteydessä vuosina 2012-2014 ja keväällä 2015. Taustatietolomakkeen kysymykset ovat suurimmaksi osaksi rastitettavia, ja osallistuja voi valita useamman kuin yhden vaihtoehdon. Lomakkeessa kysytään osallistujan sukupuoli, ikä, äidinkieli, koulutustausta, ammattiala, kohdekielen opiskelupaikka ja -aika, kohdekielen käytön taajuus kotona, työssä, vapaa-aikana ja opinnoissa sekä osallistujan oma arvio tutkintokielen hallinnasta. Näiden lisäksi kysytään, millaisiin tarkoituksiin osallistuja aikoo tutkintotodistusta käyttää (mm. hakeakseen Suomen kansalaisuutta, työnhakuun, osoittaakseen kielitaitonsa nykyiselle työnantajalle, opiskeluun, saadakseen palautetta kielitaidosta).

Virolaisista suurin osa suorittaa yleensä suomen keskitason tutkinnon (B1, B2), koska keskitason kielitaitoa pidetään työelämän kannalta riittävänä ja se on myös tärkeä Suomen kansalaisuutta hakiessa. Esimerkiksi vuosien 2012-2014 ja kevään 2015 aikana suomen keskitason tutkintoon osallistui 1033 virolaista, mikä on kaikista tutkintoon osallistuneista noin $6 \%(\mathrm{n}=21$ 697). Virolaisista $63 \%$ ilmoitti taustatietolomakkeessa tarvitsevansa todistusta hakeakseen Suomen kansalaisuutta. Työhakua varten todistusta kertoi käyttävänsä $43 \%$ ja opiskeluun $34 \%$ virolaista tutkintoon osallistujaa. Muissa tutkintotasoissa osallistujamäärä on huomattavasti keskitasoa pienempi. Keväällä ja syksyllä järjestettävillä tutkintokerroilla perustason tutkintoon (A1, A2) osallistuneita on tavallisesti vain muutama virolainen ja ylimmän tason (C1, C2) tutkinnossa on testikerralla n. 12-15 virolaista osallistujaa, jotka tarvitsevat todistusta lähinnä työelämää varten.

Tutkintotulosten perusteella virolaiset menestyvät hyvin. Hyvien tutkintotulosten taustalla vaikuttavat usein osallistujien hyvä koulutustausta ja kohdekielen käytön taajuus. Taustatietolomakkeesta saatujen tietojen mukaan virolaiset muodostavat hyvin koulutetun joukon pääosin nuorehkoja henkilöitä, joista enemmistö on naisia (75\%). Suurimmalla osalla osallistujista on joko yliopisto- (27\%) tai ammatillinen $(28 \%)$ koulutus ja he toimivat työelämässä (40\%), mutta useat ovat myös työttömänä $(20 \%)$ tai työvoimapoliittisessa koulutuksessa 
(19 \%). Omasta mielestään nämä osallistujat sekä puhuvat, kirjoittavat että ymmärtävät suomea melko hyvin tai hyvin ${ }^{1}$. Tätä vahvistaa tieto, että virolaiset osallistujat käyttävät arjessaan paljon suomen kieltä, sillä heistä 57 \% kertoi lähes päivittäin käyttävänsä suomea ystävien ja tuttavien kanssa ja seuraavansa suomenkielistä mediaa (78 \%). Suomea käytettiin päivittäin myös työssä (71 \%) ja jokapäiväisten asioiden hoitamisessa (73\%).

Tarkasteltaessa virolaisten tutkintotuloksia on tarpeellista huomioida osallistujien ensikieli, sillä oletettavasti vironkielisille on testin suorittaminen viron ja suomen kielisukulaisuuden vuoksi helpompaa kuin venäjää äidinkielenään puhuville virolaisille.

Vuosina 2012-2014 ja keväällä 2015 suomen keskitason testiin osallistuneista 1033 virolaisesta 364 henkilöä ilmoitti äidinkielekseen venäjän ja 669 henkilöä kertoi puhuvansa äidinkielenään viroa. Jos verrataan virolaisten testituloksia äidinkielen perusteella, äidinkieleltään vironkieliset menestyvät suomen keskitason tutkinnossa ${ }^{2}$ selvästi venäjänkielisiä paremmin. Tämä näkyy jokaisessa tutkinnon osataidossa, sillä vironkieliset saavuttavat ymmärtämisen taidoissa helposti taitotason $4(\sim \mathrm{B} 2)$. Tekstin ymmärtämisestä n. 80 \% vironkielisistä sai todistukseensa taitotasoarvion 4 ja puheen ymmärtämisestä $69 \%$. Venäjänkieliset menestyivät myös hyvin ymmärtämisen osataidoissa, sillä useat heistä saavuttivat tekstin ymmärtämisessä taitotason 4 (53\%), mutta puheen ymmärtämisessä suurimman osan (63\%) taidot arvioitiin taitotasolle $3(\sim \mathrm{B} 1)$. Tuottamisen taidoissa lähisukukielen merkitys näkyi ymmärtämisiä selvimmin. Puhumisen osakokeesta vironkielisistä jopa $70 \%$ sai taitotasoarvioiksi 4, kun venäjänkielisistä $33 \%$ ylsi tälle taitotasolle. Pääosa saavutti tutkinnon läpäisytason 3 (58 \%), joten kokonaisuudessaan virolaisten testiin osallistuneiden suomen kielen puhumisen taito on hyvä, on taustalla sitten äidinkielenä joko venäjä tai viro. Kirjoittaminen on osoittautunut Yleisissä kielitutkinnoissa viime vuosina varsin vaikeaksi

\footnotetext{
1 Asteikko: huonosti / melko huonosti / melko hyvin / hyvin.

2 Keskitasolla suorituksista voi saada arvioin $<3$ (ei vielä saavuttanut keskitason vaatimuksia), 3 ( $\sim \mathrm{B} 1)$ ja 4 ( $\sim \mathrm{B} 2)$.
} 
taidoksi verrattuna muihin osataitoihin. Vironkielisistä vajaa $50 \%$ saavutti kirjoittamisessa taitotason 4 ja $48 \%$ taitotason 3. Venäjänkielisistä taas $24 \%$ ylsi taitotasolle 4 ja taitotasolle 3 yltäneitä oli $70 \%$. Kirjoittamista myös osallistujat itse pitivät itselleen vaikeimpana taitona, sillä heistä neljännes arvioi kirjoittavansa melko huonosti suomea. He myös kertoivat kirjoittavansa vähän suomeksi; enemmistö heistä ilmoitti kirjoittavansa suomeksi vain kerran kuussa tai harvemmin (23\%) tai kerran tai pari kertaa viikossa (37\%). Kuitenkin verrattuna muihin testiin osallistujiin virolaiset saavuttivat keskitason kriteerit hyvin kirjoittamisen osakokeessa.

Virolaisten ja vironkielisten osallistujien kielitaito vastaa hyvin tutkintotasolla vaadittuja vähimmäiskriteereitä, ja arvioijien mukaan ongelmana onkin lähinnä se, jääkö arvosana 3:en vai mennäänkö jo nelosen puolelle (Kristiina). Arvioija Kristiinan lauseesta tulee lisäksi hyvin esiin se, että arvioijat peilaavat omia arviointikokemuksiaan mielellään keskitason suorituksiin. Kaikilla suomen arvioijilla on paljon kokemusta keskitason suoritusten arvioinnista, sillä keskitason arviointitilaisuuksia järjestetään vuosittain kahdeksan kertaa. Tästä syystä myös seuraavissa arvioinnin helpoissa ja vaikeissa asioissa arvioijat usein viittaavat juuri keskitason tutkintoon osallistuneisiin vironkielisiin.

\section{Helpot asiat vironkielisten arvioinnissa}

\subsection{Hyvät testitekniset taidot ja kokemus kielitesteistä}

Testitilanteessa monet asiat vaikuttavat osallistujan suoritukseen. Tutkinnon suorittaminen edellyttää aina tehtäväohjeiden huolellista lukemista ja ymmärtämistä, sillä testiarvioinnissa evidenssi kielitaidosta ilmenee ainoastaan tehtävien avulla. Verrattuna luokkahuonearviointiin osallistuja ei voi todistaa kielitaitoaan esim. tuntiaktiivisuudella, vaan testiarviointi on ainutlaatuinen tilanne, jossa mitataan vain juuri senhetkistä kielitaitoa. Sillä, kuinka osallistuja tulkitsee ja ymmärtää tehtäviin liittyvät ohjeet ja osaa toimia testitilanteessa, on merkitystä tutkintosuorituksen onnistumiselle. Yksikielisessä testissä, jollainen suomen 
kielen tutkinto on, kaikki ohjeet ja tehtävänannot ovat kohdekielellä, joten päästäkseen testistä läpi on osallistujalla oltava hallussaan jo jonkin verran testiteknistäkin sanastoa. Tekstiteknisen sanaston ja tehtävien sisällön ymmärtäminen on tärkeää, sillä tehtävän avulla määritellään se, mistä osallistujan halutaan puhuvan tai kirjoittavan. Samoin testitilanne on sitä helpompi, mitä enemmän osallistujalla on kokemusta vastaavista testi- tai koetilanteista.

Arvioijien vastausten perusteella vironkieliset ymmärtävät hyvin suomeksi kirjoitetut tehtävänannot ja testissä annetut ohjeet. Heidän suorituksiaan arvioidessa arvioija voi keskittyä suorituksen kielelliseen tuotokseen eikä hänen tarvitse miettiä, miten oikein tai väärin tehtävänanto on tulkittu ja kuinka tämä vaikuttaa lopulliseen taitotasoarvioon. Vironkielisten osallistujien suomen kielen ymmärtämisen taito on tässä suhteessa moniin muihin osallistujiin verrattuna hyvä ja osittain tästä syystä he onnistuvat lähes poikkeuksetta tehtävien suorittamisessa.

(1) Vironkielinen osallistuja ymmärtää usein tehtävän ja ohjeet. Vastaus/ vastaukset ovat suoraan aiheesta ja tehtävänannoista. (Aili)

(2) Arvioinnissa on yleensä helppoa se, että tehtävänannon väärinymmärryksiä on suhteellisen vähän. (Hille)

(3) Haastattelutilanteessa vironkielinen ymmärtää vaikeuksitta vaikeatkin kysymykset ja vastaa niihin. Yleisvaikutelmaksi jää, että vaikeista asioista pystyttiin puhumaan ihan sujuvasti. (Maria)

Tutkintoon osallistuminen edellyttää sopivan testitason valintaa, ja vironkieliset yleensä onnistuvat hyvin valitsemaan kielitaidollisesti heille oikean tutkintotason. Kuten luvussa 5 esitetyistä tuloksista käy ilmi, vironkieliset saavuttavat hyvin keskitasolle vaaditut kriteerit eri taidoissa. Arvioijien mukaan myös vironkielisten sijoittaminen keskitason kriteereille onnistuu yleensä vaivatta.

(4) Yleensä osaavat suomea tosi hyvin, joten keskitasoa arvioitaessa on helppo lätkäistä nelonen sen ihmeempiä miettimättä. (Liisi)

(5) Helppoa on se, että monet vironkieliset osaavat suomea hyvin ja ovat ns. varmoja/selviä kolmosia tai nelosia. (Ursula) 
Arviointitilanne on arvioijan näkökulmasta kognitiivisesti raskasta. Arviointipäivänä arvioidaan useita suorituksia, ja arviointi vaatii monesti tekstien uudelleenlukua tai puhetuotosten uusintakuuntelua, jotta lopullinen arvio suorituksesta on mahdollista antaa. Vironkielisten arviointia pidetään tässä mielessä helppona, sillä lopullisen taitotason päättäminen selkeän ja jäsennellyn näytteen jälkeen on helpompaa kuin tuotoksen, joka edellyttää arvioijalta paljon arvaamista, omaa tulkintaa ja uudelleenkuuntelua/-lukemista.

(6) Joskus kun arvioinnissa vireystila on päässyt laskemaan monen epäselvän ja alkeellisen näytteen takia, kaivan pinosta usein jonkun virolaisen, koska tiedän, että voin hengähtää välillä eikä arvioiminen ole niin työlästä. (Monika)

\subsection{Samankaltainen kulttuuri ja ajattelutapa}

Yleiset kielitutkinnot on kansallinen kielitutkinto, jossa kielitaitoa testataan suomalaisessa kontekstissa. Kielitaitoon osallistuminen edellyttää siis aina jonkin verran myös suomalaisen kulttuurin ja yhteiskunnan tuntemusta, vaikka testitehtävät pyritään laatimaan siten, että ne eivät sisällä kulttuurispesifisiä elementtejä ja käsitteitä. Vironkielisten tietämys Suomesta ja suomalaisesta yhteiskunnasta on monella tapaa parempi kuin sellaisilla tutkintoon osallistuneilla, joiden lähtömaa maantieteellisesti on kaukana Suomesta ja joiden kulttuuri poikkeaa suomalaisesta kulttuurista. Typologiselta rakenteeltaan suomen kaltainen kieli ja kulttuurisesti Suomen kulttuurin kanssa läheinen kulttuuri helpottavat suomen kielen oppimista, vaikkakaan virolaisilla ei välttämättä olisi taustalla yhtä paljon suomen opiskelua kuin muilla testiin osallistujilla (Martin 1999: 168; Suni 1996). Useat testitehtävissä käytettävät kielenkäyttötilanteet ja aihepiirit ovat vironkielisille tuttuja oman kielen kautta ja käsitys ympäröivästä yhteiskunnasta, sen ilmiöistä ja ongelmista on varsin samankaltainen kuin suomalaisilla.

(7) On helpompi ymmärtää sukulaiskieltä ja sukulaiskansan edustajan esitystä asioista, koska asioiden kuvaaminen ja perusteleminen - tapa 
ajatella asioita - on meille tutumpaa kuin vaikkapa Thaimaasta tai Gambiasta tulevien. (Alina)

(8) Keskitason virolaista puhujaa on yleensä helppo ja mukavakin arvioida; hän osaa rakentaa tuotoksensa tehtävänannon mukaisesti ja kulttuurisesti sopivaksi. (Annika)

Ymmärtämisen taustalla vaikuttavat tehtävän kontekstin ymmärtäminen sekä tehtävässä tarvitun maailmantiedon määrä (mm. Alderson 2000). Jos testiin osallistuvalta puuttuu tehtävän vaatima maailmantieto tai se poikkeaa kovasti yleisestä, kulttuurissa vallalla olevasta ajattelutavasta, se saattaa vaikuttaa osallistujan testitulokseen. Esimerkiksi kirjoittamisessa tuotetaan tavallisesti sellaisia tekstejä, jotka ovat omalle kulttuurille luonnollisia mutta jotka eivät välttämättä ole lukijalle tuttuja. Vaikka asioita voidaan kuvata ja esittää neutraalisti ja jopa universaalisti, aihepiirin ja kielenkäyttötilanteen perusteella oppija saattaa kokeessa törmätä uusiin sosiaalisiin käytänteisiin ja tietoihin aihepiiristä ja kielenkäyttötilanteesta riippuen. (Eskey 2005: 570.)

\subsection{Arviointia ohjaavien kriteereiden täyttyminen}

Yleisten kielitutkintojen tutkinnot nojautuvat toiminnalliseen ja kommunikatiiviseen kielitaitokäsitykseen, jossa kielenkäyttö nähdään osana yksilön normaalia jokapäiväistä elämää. Selviäminen edellyttää kielenkäyttötilanteessa ymmärretyksi tulemista, ja tästä syystä myös arvioinnissa "ymmärrettävyys" on tärkeä kriteeri määriteltäessä kielitaidon tasoa. Ymmärrettävyyteen (engl. intelligibility ja comprehensibility) vaikuttavat monet asiat, kuten puheessa ääntäminen tai aksentti, kirjoittamisessa taas käsiala tai puutteellinen koherenssi. Ymmärrettävyyden taustalla ovat usein lisäksi kielenoppijan sanastolliset tai rakenteelliset puutteet, jotka laajuudesta riippuen voivat haitata tai jopa estää ymmärretyksi tulemista. Arvioijien vastausten perusteella vironkielisten tuotoksissa virheet eivät ole yleensä asian merkitystä haittaavia, vaan virheet ovat vähäisiä ymmärrettävyyden näkökulmasta. 
(9) Kokemukseni mukaan vironkieliset saavat asiansa helposti perille omalla taitotasollaan, vaikka saattavat tehdä paljon kielioppivirheitä, sillä heidän virheensä eivät ole niin usein merkitystä muuttavia. (Virve)

(10) Puhetta on helppo kuunnella ja asia tulee kohtalaisen helposti ymmärretyksi, vaikka siellä olisikin viron ilmaisuja tai sanoja tai intonaatio, nuotti poikkeaa suomesta. (Maire)

Toinen yleinen kriteeri etenkin puhumisen arvioinnissa on sujuvuus (engl. fluency). Sujuvuudella on taidosta riippuen useita määritelmiä. Puheessa sujuvuus viittaa yleensä puheen kieliopin tai ääntämisen virheettömyyteen tai nopeuteen (Ullakonoja 2011: 23-29), mutta siihen usein liitetään myös käsitteet jatkuvuus ja helppous (Toivola 2011: 14). Lisäksi taukojen määrä puheessa yhdistetään sujuvuuteen, sillä puheessa on kyse reaaliaikaisesta kielen tuottamisesta, jossa turhat tauot ja epäröinti sekä hidas puhenopeus ovat usein merkkejä kielitaidon puutteesta tai tarpeesta prosessoida vierasta kieltä (Ellis \& Barkhuizen 2005: 139; Piske ym. 2001).

Kirjoittamisessa sujuvuuden on nähty myös olevan yhteydessä tuottamisen nopeuteen (Ellis \& Barkhuizen 2005: 157; Chenoweth \& Hayes 2001). Testitilanteessa osallistujalle annetaan tietty aika kirjoittamisen tehtävien suorittamiseen, joten ajalla on merkitystä testattaessa kirjoittamisen taitoa. Yleisten kielitutkintojen kirjoittamisen testissä tuotosten pituudella ei ole niin suurta merkitystä kuin kielellisillä seikoilla ja tehtävän funktion täyttymisellä. Tästä syystä sujuvuus testitilanteessa on ennemminkin sitä, miten ymmärrettävää, sidosteista ja koherenttia tekstiä osallistuja pystyy tuottamaan annetussa ajassa määritellystä aiheesta. Nopeus on enemmän yhteydessä tekstin lukijaan: jos teksti on sujuvaa, on sen lukeminen myös nopeaa eikä lukijalta katkea lukurytmi tekstiä lukiessaan.

Arvioijista vironkielisten tuotokset ovat yleensä sujuvia ja helppoja sekä lukea että kuunnella eikä niiden arviointi vaadi arvioijalta ylimääräisiä ponnistuksia.

(11) Puheen että kirjoittamisen sujuvuus yleensä todella hyvä, hyvät tuottamisvalmiudet. Melko luontevaa heikommallakin kielitaidolla. (Siiri) 
(12) Helppoa on yleensä sujuvuus: sanat ja lauseet soljuvat yleensä normaalitempossa, eikä ajatuksen pysäyttäviä katkoja ei ole paljon. (Helja)

(13) Ei tarvitse arvailla merkityksiä. Puhe ja kirjoitus sujuvaa, sujuvampaa kuin sillä taitotasolla yleensä. (Tuuli)

Ääntäminen vaikuttaa niin ymmärrettävyyteen kuin sujuvuuteenkin (Aho 2004: 11; Munro \& Derwing 1995). Ääntämisen selkeys ja tuttuus ovat ennen kaikkea yhteydessä ymmärrettävyyteen, mutta ääntäminen kantaa mukanaan myös paljon sosiaalista tietoa itse puhujasta. Kun kuulemme erilaisia variaatioita kielestä, kiinnitämme huomiota niin kielellisiin kuin kielen ulkoisiinkin seikkoihin ja teemme niiden pohjalta päätelmiä puhujan henkilökohtaisista ja sosiaalisista ominaisuuksista. (Lippi-Green 1997; Cargile ym. 2010: 61; Street \& Hopper 1982: 175.) Taustalla vaikuttavat kuuntelijan kokemukset ja ajatukset sekä asenteet puhujan edustamasta sosiaalisesta ryhmästä (Cargile \& Giles 1997: 196). Nämä saattavat synnyttää erilaisia stereotypioita tai herättää tunteita, jotka ilmenevät mieltymyksenä tai vastenmielisyytenä jotain ääntämystapaa kohtaan. Vierasperäinen korostus on usein helppo tunnistaa jo varsin vähäisestä puhemateriaalista. Syntyperäinen kielenpuhuja kuulee ensisijaisesti poikkeavan intonaation, ja prosodisten piirteiden perusteella syntyperäinen kuulija myös usein arvioi puhujan kielitaitoa keskittymättä niinkään kielioppivirheisiin tai yksittäisiin äännevirheisiin. (Anderson-Hsieh ym. 1992.) Arvioijat tunnistavat hyvin helposti vironkielisen suomen puhujan intonaatiosta, äng-äänteen puuttumisesta sekä soinnillisista konsonanteista: d:n ääntäminen paljastaa virolaisen aina (Siiri). Tunnistettavuudesta ja ääntämisen puutteista huolimatta arvioijat pitivät vironkielisten suomen kielen ääntämystä hyvänä.

(14) Ääntäminen, vaikka olisi kuin virolainen intonaatio, ei ole tuskaisaa kuunneltavaa, koska se on tuttua ja muistuttaa omaamme. (Alina)

(15) Eestin intonaatio on tuttua ja antaa suomen kielen käyttämisestä sulavan vaikutelman, vaikkei täysin virheetöntä olisikaan. (Pille)

Viron kielessä on piirteitä, joiden vuoksi vironkielisen puhe saatetaan yhdistää jopa murteelliseen suomeen, lähinnä lounaismurteisiin, jotka ovatkin suomen murteista viroa lähimpänä. 
(16) Ei juurikaan aksenttia, puhe kuulostaa suomelta pienin maustein. (Siiri)

(17) Helppoa, helpon tuntuista on soljuva, kotoinen puheen lauserytmi antaa vaikutelman, että olisi kuuntelemassa jotain suomen murretta. (Ulla)

Koska kielet ovat lähellä toisiaan, vironkielisten ääntämys ei aiheuta samankaltaisia ongelmia kuin esimerkiksi sellaisten puhujien, joille jotkin suomen äänteet (mm. $r, \ddot{a}$ ja $\ddot{o})$ tuottavat hankaluuksia.

(18) Monesti myös ääntämys on hyvin virolaista, ei kohdekielimäistä. Se ei vaikuta ymmärrykseen niin paljon kuin esim. kiinalaisen puhujan ääntämysvirheet, mutta ei kuitenkaan ole suomea. (Kristiina)

Toisessa tuottamisen taidossa, kirjoittamisessa, kirjoittajan ensikieli voidaan tunnistaa usein käsialasta tai tekstin asettelusta paperille. Osalle tutkintoon osallistuneille saattaa olla jopa vierasta kirjoittaa viivan yläpuolelle eikä kirjoittamisen kulttuuri ole niin tuttua kuin meille länsimaisen koulutuksen saaneille. Vironkielisten tutkintoon osallistuneiden kirjoittamisen suorituksia on helppo arvioida, sillä heillä on koulutuksen tuomat taidot kirjoittaa jäsenneltyä tekstiä.

(19) Kirjoitetaan lauseita, isot ja pienet alkukirjaimet ovat kohdallaan ja kirjoitus on aseteltu paperille tehtävänannon mukaisesti. Pidemmissä teksteissä on usein jaksotusta yms. Nämä ovat asioita, jotka nousevat positiivisina esiin, koska ne niin usein näytteistä puuttuvat. (Monika)

(20) Käsiala ei yleensä tuota virolaisilla ymmärtämisvaikeuksia ja heillä on koulutuksen ansiosta kyky tuottaa tekstimäisiä tuotoksia. (Ursula)

Kirjoittaminen on tuottamisen taidoista sikäli puhumista haastavampi, että puheessa tehdyt virheet eivät jää näkyviin, mutta kirjoittamisessa vironkielisille tyypilliset virheet kuitenkin tulevat usein esiin, vaikka niiden ei katsottu haittaavan viestin perillemenoa ja ymmärtämistä.

(21) Oikeinkirjoitusvirheet ovat ennustettavia, eivätkä ne aiheuttaisi todennäköisesti ymmärtämisvaikeuksia edes suomenkieliselle, jolla ei ole yhtään tietoa viron kielestä. (Helja) 
(22) Vironkielisten puhumisen arvioiminen tuntuu ylipäätään helpommalta kuin kirjoittamisen. Johtunee siitä, että puheessa "virolaisuudet" eivät häiritse samalla tavalla kuin kirjoituksessa. (Maria)

(23) Myös kirjoittamisessa klusiilien erottaminen vaikeaa. Lauserakenteet usein virolaisia, esim. terminatiivin käyttö. (Siiri)

Koska kielet ovat rakenteellisesti, sanastoltaan ja funktionaalisesti samankaltaisia, samankaltaisuudella on paljon positiivisia vaikutuksia (esim. Martin 2006: 46). Kuitenkin samankaltaisuus saattaa aiheuttaa myös negatiivisia vaikutuksia, interferenssiä, kuten Kaivapalu (2009: 385) on vironkielisten opiskelijoiden suomen oppijakielestä havainnut. Seuraavassa kappaleessa nostamme esiin arvioijien mainitsemia asioita, jotka he kokivat vaikeiksi arvioidessaan viron kieltä äidinkielenään puhuvien suorituksia.

\section{Vironkielisten arvioinnissa vaikeuksia aiheuttavat asiat}

\subsection{Kielten samankaltaisuus}

Suurin osa arvioijien mainitsemista vaikeuksista arvioida vironkielisten suorituksia liittyi niin suomen ja viron kielten rakenteiden ja sanaston kuin kielten funktioidenkin samankaltaisuuteen (esim. Hassinen 2002; Kaivapalu 2005; Martin 2006; Nissilä 2011). Pääasiassahan lähisukukielen vaikutukset ovat positiivisia arvioinnin näkökulmasta, mutta samankaltaisuudet aiheuttavat epävarmuutta arviointitilanteessa. Näin erityisesti kielitaidon kehittyessä pidemmälle, jossa kielenkäyttäjältä jo odotetaan varsin tarkkaa ja idiomaattista kielen osaamista. Edistyneillä vironkielisillä suomen kielen oppijoilla on tutkimusten mukaan haasteita sekä rakenteiden että sanaston hallinnassa (Nissilä 2011). Nämä vaikeudet ovat usein yhteydessä sellaisiin seikkoihin, joissa oma äidinkieli eroaa suomesta rakenteeltaan ja sanastoltaan (Martin 1999: 162-163). Kielitesteissä vironkieliset tukeutuvat omaan äidinkieleensä tilanteissa, joissa suomen kielen taito puuttuu. 
(24) Ikuisuuskysymys on, kuinka paljon voi "antaa anteeksi" viron kielen vaikutusta tai jopa suoraan virolaisia muotoja (sekä rakenteissa että sanastossa), jos viesti tulee kuitenkin ymmärretyksi - tulee mieleen, että on "oikeaa osaamista", jos osaa jotain, mikä on sama tai melkein sama omalla kielellä - ja sitten taas toisaalta, miksi se ei olisi?! (Maria)

Kielten lähisukulaisuus ja rakenteellinen samankaltaisuus usein johtavat siihen, että virolaisista rakenteista ja sanoista huolimatta tuotos on ymmärrettävä.

(25) Kun puhuja käyttää sanoja, jotka eivät ole ihan korrektia suomea, on vaikea pysyä arvioinnissa objektiivisena, koska ymmärtää kuitenkin yleensä, mitä hän sanoo/kirjoittaa. (Pille)

(26) Tietyt viron kielen piirteet ovat hyvinkin tunnettuja Suomessa ja merkitysten arvattavuus ei välttämättä vaikeuta kommunikaatiota syntyperäisten suomalaisten kanssa niin paljon, kun puristinen tulkinta antaisi odottaa. (Helja)

Arvioijia kuitenkin mietitytti se, millä tavalla tällainen "sekakieli" on ymmärrettävää jokapäiväisessä elämässä. Opettajana he ovat tottuneet kuuntelemaan virheellistä suomea, jossa saattaa olla vaikutteita kielenkäyttäjän omasta äidinkielestä, mutta arvioinnissa täytyy aina ajatella myös sitä, miten testistä annettu arvio ennustaa osallistujan selviytymistä vastaavissa tilanteissa jokapäiväisessä elämässä.

(27) Arvioinnissa ärsyttää se, että viron erottaminen suomen kielestä on vaikeaa ja vaatii tarkkuutta; arvioija joutuu pysähtymään ja kieltäytymään ymmärtämästä ja hyväksymästä tuotosta, jonka ymmärtää, koska on verrattava kadunmieheen, joka ei hallitse viron kieltä. (Alina)

Koska viron kieli on hyvinkin tuttu monelle suomalaiselle, tietyt vironkielisyydet puheessa eivät välttämättä herätä samanlaisia tuntemuksia kuin jonkin muun kielen sanat. Puhutussa kielessä ne saatetaan hyväksyä autenttiseen puheeseen kuuluvina "täytesanoina", joiden avulla täytetään taukoja suunniteltaessa sanottavaa.

(28) Kun venäläinen puhuja toistaa: $n u, n u$, tak, nu tak on arvioijana helpompi ajatella, että puhuja tuo selvästi oman kielen sanastoa puhee- 
seensa, joten ei kelpaa, mutta kun virolainen sanoo oman kielensä sanoja: kas, kus, ise, töö, milline, selline, midagi, aga, ne luovat usein hilpeyttä, kuulostavat hauskoilta, mistä seuraa se, että joutuu ravistelemaan itseään olemaan hyväksymättä viron kieltä suomen kielen testissä. (Hannele)

\subsection{Testin toiminnallinen luonne}

Funktionaalisessa tutkinnossa kieltä katsotaan ymmärrettävyyden näkökulmasta. Arvioitaessa vironkielisten suorituksia usein väistämättä kuitenkin törmätään kysymykseen, kuinka suhtautua tuotokseen, joka on ymmärrettävää, mutta ei suomen kieltä.

(29) Tasapainoilu, joka tuntuu ideologiselta: missä ovat kielten rajat, ja onko niitä syytä piirtää? (vrt. "Kieli on murre, jolla on oma armeija ja laivasto") Jos mitataan kommunikatiivista kielitaitoa, tämä on minusta vaikea kysymys. (Laura)

Arvioinnissa kyse on suomen kielen osaamisen määrittelystä, joten tuotoksissa on myös huomioitava, missä määrin osallistuja voi tukeutua omaan äidinkieleensä. Ongelmia taitotason määrittämiselle aiheuttaa se, että suurimmalle osalle arvioijista viron kieli on enemmän tai vähemmän tuttu ja arviointitilanteessa arvioijalla itsellään myös kielten raja hälvenee.

(30) Joutuu miettimään, mikä puheessa on suomea ja mikä viroa, kun sanoma tulee suhteellisen helposti ymmärretyksi. Kuulijana ymmärrän "liian" hyvin ja hankalien ilmaisujen kohdalla haen päästäni viron kielen ilmaisua. (Maire)

(31) Arvioinnissa on vaikeaa ennen kaikkea suomen ja viron kielen läheisyys - ja lisäksi se, että osaan itsekin viroa. Näin ollen mun on välillä vaikeaa tietoisesti erottaa, onko puhujan käyttämä sana suomea vai viroa ja miten mun tulisi kyseistä seikkaa näin ollen arvioida. (Jaana)

Arvioinnin kannalta arvioijat pitivät ongelmallisena vironkielisten kohdalla sitä, miten paljon tunnistettavissa olevia korrektin viron mukaisia ilmauksia, jotka suomen kielen mukaan ovat virheellisiä, voidaan hyväksyä ja kuinka niistä pitää osallistujaa rangaista. 
(32) Kuinka paljon pitäisi "rokottaa" rakenteellisista virheistä, joista tietää, että se on suoraan viron kielestä? (Kristiina)

(33) Miten suhtautua esimerkiksi sananvalintavirheisiin (riskisanat), kvantiteettiin, sijojen käyttöön vaikkapa verbien rektioiden yhteydessä, astevaihteluun tai vokaalisointuun. Kun nämä eivät aiheuta väärinkäsityksiä ja kun ymmärrän puhujaa, nämä eivät ole ongelmia keskitasolla. (Annika)

Arvioija Monikan mielestä funktionaalinen testi antaa luvan tehdä virheitä ja tärkeintä on onnistua kielenkäyttötilanteissa, joissa virolaiset onnistuvat tavallisesti keskitason vaatimusten mukaisesti.

(34) Virolaiset pärjäävät luultavasti yleensä hyvin ykissä ainakin keskitasolla, koska mitataan kielenkäyttötaitoja, ei oikeellisuutta. (Monika)

Funktionaalinen kielitaitokäsityksessä kieli nähdään osana sosiaalista toimintaa ja vuorovaikutuksen välineenä (EVK 2003), jossa kielenkäytön tärkein tehtävä on luoda merkityksiä. Tämä ei kuitenkaan tarkoita sitä, että osallistujan ei tarvitse hallita kielen rakenteita. Rakenteet ovat aina sidoksissa kielenkäyttöön, ja tieto kielen rakenteista on yksi kielenkäyttäjän tarvitsemista kompetensseista. Kielitaidon puutteet ja virheellisyydet kuuluvat olennaisena osana kielitaidon arviointiin samoin kuin äidinkielen vaikutus. Virheellisten piirteiden huomaaminen on usein helpompaa, ja niihin saatetaan takertua liiaksikin. Yleisten kielitutkintojen arvioinnissa ei kuitenkaan keskiössä ole yksittäisten virheiden löytäminen ja niistä rankaiseminen, vaan oleellisempaa on tuotoksen kokonaisuus ja sen ymmärrettävyys.

\subsection{Kielen käytön rajoitteet}

Suurin osa arvioijista piti virolaisten suomen kielen ääntämistä hyvänä, mutta heidän tuotoksessaan ääntämys kuitenkin usein paljasti puhujan alkuperän. Viro on äänteellisesti lähellä suomea, joten virolaisilla osallistujilla ei ole tarvetta välttämättä kovasti kiinnittää huomiota suomen kielen ääntämiseen. Tässä kuitenkin saattaa piillä ongelmia arvioinnin näkökulmasta. 
(35) Puheen nopea rytmi ja lauseintonaatio tuottavat vaikeuksia, ja arviointia varten puhetta joutuu kuuntelemaan uudelleen; virolainen puhuja olettaa helpommin kuin joku muun kielen puhuja, että vaikka hän tuo puheeseensa puhtaasi virolaisia ilmauksia, kuulija ymmärtää häntä, mistä johtuu, ettei hän tauota, anna aikaa ja tilaa kuulijan ymmärtämiselle. Virolaiset ovat tottuneet siihen, että he selviävät suomalaisten kanssa jotenkuten omalla kielellään. (Alina)

Vieraskielinen ääntämys voi toisaalta olla puhujalle myös suojamuuri, että hänen ei tarvitse osata kieltä täydellisesti ja vihje kuuntelijalle myös siitä, että puhuja ei vielä välttämättä hallitse kaikkia kohdekielen pragmaattisia periaatteita (Nikula 2000: 350-351).

Aivan kuten ääntäminen, nähtiin myös sujuvuus sekä positiivisena että negatiivisena piirteenä. Vironkielisten tuotoksia pidettiin yleensä sujuvina, mutta joissain tapauksessa sujuvuuden mainittiin peittävän muut puutteet kielitaidossa.

(36) Virolainen puhuu "sujuvasti", mutta tarkemmalla kuuntelulla osaaminen voi olla pintaosaamista, ei osaa esim. rektioita, puhuu viroa ja suomea sekaisin. Siis virolainen voi puhua suhteellisen sujuvasti (nopeasti), mutta on vaikea antaa esim. nelosta, jos jokaisessa lauseessa on tarkkuusvirheitä. (Elli)

(37) Vaikeata on se, että vironkielisten osallistujien puheessa ja teksteissä on usein sujuvuutta mutta toisaalta interferenssiä, mikä tekee arvioinnin vaikeaksi eli pitäisikö vironkielisistä sanoista "rokottaa". (Hille)

Arvioijat käyttivät sujuvuudesta nimitystä pintasujuvuus. Puhe voi olla hyvin sujuvalta kuulostavaa ja virheetöntäkin, mutta kyse on vielä pintatason oppimisesta. Kieli kehittyy kahtena ulottuvuutena: pintasujuvuutena ja ajattelun kielenä. Kielitaidon alkuvaiheessa pintasujuvuus usein riittää arkipäiväisissä kielenkäyttötilanteissa käsiteltäessä varsin konkreettisia asioita. (Skutnabb-Kangas 1989.) Varsinkin kielitaidon alkuvaiheessa kielenoppija voi selvitä ulkoa opittujen fraasien perusteella tutuissa tilanteissa. Ajattelukieli taas liittyy enemmän miettimistä vaativiin tilannesidonnaisiin ongelmaratkaisutilanteisiin, jolloin kielen tehtävänä on antaa tai välittää tietoa. (Skutnabb-Kangas 1988: 77.) 


\subsection{Kielen tuttuus vs. oma arviointilinja}

Laadukkaan arvioinnin yksi kriteereistä on eettisyys, jolla viitataan siihen, että arviointi tukee osallistujan minäkäsitystä lannistamatta tai liioittelematta. (Huhta \& Takala 1999; Tarnanen 1998.) Eettisyys on yhteydessä myös epävarmuuteen arviointihetkellä. Arvioija pyörittelee usein mielessään kysymystä, mikä on oikea arvio tuotoksesta tai onko oma arvio oikeudenmukainen arvio suorituksesta. Vironkielisiä osallistujia arvioidessaan arvioijat kertoivat vastauksissaan miettivänsä useinkin omaa arviointilinjaansa. Käsitykset omasta arviointikäyttäytymisestä olivat kuitenkin kaksitahoisia. Osa koki, että he suhtautuvat liian lempeästi vironkielisten suorituksiin ja ovat kielen samankaltaisuuksien vuoksi hyväksyneet heiltä enemmän puutteita kuin muilta.

(38) Vironkieliset sitä vastoin voivat olla hyvinkin sujuvia -eikä arvioija loppujen lopuksi ole varma, kuunteliko suomea vai viroa :). Virolaiset siis saattavat onnistua kielikokeessa paremmin kuin heidän kielitaitonsa itse asiassa edellyttäisi. (Monika)

(39) Muilla kuin vironkielisillä arvioitavilla tämä kielten toisistaan erottaminen on paljon helpompaa, koska muut kielet eroavat yleensä suomesta selvästi. Joskus olen jäänyt jopa miettimään sitä, ymmärränkö vironkielisten suomea (tai suomi-viro-sekoitusta) liian hyvin ja arvioinko heitä siksi liian lempeästi. (Jaana)

Osa taas pohti, suhtautuvatko he puolestaan liian kriittisesti vironkielisten suorituksiin ja nouseeko taitotasojen rima korkeammaksi heidän kohdallaan. Vironkielisiä pidetään yleisesti hyvinä suomen taitajina ja taitotasovaatimukset saatettiin siitä syystä nostaa tavallista korkeammalle.

(40) Toisaalta arvioinnissa saatan suhtautua muita kieliä kriittisemmin vironkielisten suomesta poikkeavaan ääntämykseen ja ilmaisuihin. Ja sitten pitää tarkkailla omaa kritiikkiä. (Maire)

(41) Vironkielisiä kuunnellessa on joskus vaikea päättää, millainen määrä viroa on hyväksyttävää suomen kielen suorituksessa. Hyväksynkö viron kielen vaikutuksen esim. ääntämyksessä ja muoto-opillisissa jutuissa helpommin kuin vastaavanlaiset "puutteet" vaikkapa venäjää/arabiaa 
äidinkielenään puhuvan suorituksessa? Arvioinko liian löysästi tai liian tiukasti? (Irja)

\section{Pohdintaa}

Arvioijien antamat vastaukset kuvastavat, että vironkielisten suoritusten arviointi ei ole suoraviivaista arviointikriteerien konemaista toistoa, vaan arvioijat usein reflektoivat arviointiaan ja oman toimintansa oikeutusta. Tällainen esimerkkien kaltainen oman arviointityön reflektointi on tärkeä osa arvioijana toimimista ja arvioinnin luotettavuuden parantamista. Itsereflektion kautta arvioijalle kehittyy kyky ohjata ja vaikuttaa omaan arviointiprosessiinsa (Tarnanen 2014: 122). Onnistunut arviointi ei ole vain standardien ja sääntöjen noudattamista, vaan tarvitaan myös sensitiivisyyttä yksittäisen osallistujan suoritusta kohtaan (Attali 2016: 108). Tällöin on hyvä tunnistaa ne käsitykset, joita meistä itse kukin kantaa mukanaan ja jotka vaikuttavat esimerkiksi siihen, millainen kirjoitelma tai puhetuotos on "hyvää kieltä" ja millaisin ennakko-odotuksin me arvioimme suorituksia.

Kielitaidon arvioinnin kannalta tärkeä kysymys oikeudenmukaisuudesta heijastuu selvästi arvioijien kommenttien taustalta.

(42) Suhtautua myötämielisesti arvioitavaan tekstiin (jos siis tietää kansalaisuuden). Toisaalta pettymyskin voi olla karvas. Molemmissa tapauksissa tietenkin on vaarana lipsua ammattiarvioijuudesta eli pyrkimyksestä minimoida ulkoiset tekijät arvioinnissa. (Virve)

Oikeudenmukaisuuden merkitystä on arvioinnissa korostettu viime vuosikymmeninä. Asia on kuitenkin ongelmallinen, koska käsitykset oikeudenmukaisuudesta vaihtelevat ajassa ja paikassa. Hamp-Lyons (2000) puhuukin oikeudenmukaisuudesta monikollisena käsitteenä (engl. fairnesses). Oikeudenmukaisuuteen kuuluu esimerkiksi se, että emme anna testiin kuulumattomien asioiden johtaa arviointia. Tällaisia ovat esimerkiksi testiin osallistujan ikä, sukupuoli ja etninen tausta. On syytä kuitenkin muistaa, että arviointi on asiantuntijuutta, johon kuuluu luonnollisena osana epävarmuus ja emootiot, koska se on inhimillistä 
toimintaa (Tarnanen 2014). Testijärjestelmän tehtävänä on pyrkiä erilaisin keinon viemään arviointia mahdollisimman luotettavaan suuntaan. Tämä edellyttää jatkuvaa kaksoisarvioinnin avulla tehtävää arvioijien sisäisen johdonmukaisuuden ja arvioijien välisen yhdenmukaisuuden tarkkailua sekä arvioijien työtä kehittävän palautejärjestelmän kehittämistä.

\section{Lähteet}

Aho, Eija 2004. Prosodian aseman toisen ja vieraan kielen opetuksessa. Suomen kielen prosodian opettamisen ja oppimisen kysymyksiä. - B. Straszer, A. Brown (Toim.), Kakkoskieli 5. Helsinki: Helsingin yliopiston suomen kielen laitos, 9-94.

Alderson, J. Charles 2000. Assessing Reading. Cambridge: Cambridge University Press. http://dx.doi.org/10.1017/CBO9780511732935

Anderson-Hsieh, Janet, Ruth Johnson, Kenneth Koehler 1992. The relationship between native speaker judgments of pronunciation and deviance in segmental, prosody and syllable structure. - Language Learning 42 (4), 529555. http://dx.doi.org/10.1111/j.1467-1770.1992.tb01043.x

Attali, Yigal 2016. A comparison of newly-trained and experienced raters on a standardized writing assessment. - Language Testing 33 (1), 99-115. http://dx.doi.org/10.1177/0265532215582283

Cargile, Aaron Castellan, Howard Giles 1997. Understanding language attitudes: Exploring listener affect and identity. - Language and Communication 17 (3), 195-217. http://dx.doi.org/10.1016/S0271-5309(97)00016-5

Cargile, Aaron Castellan, Eriko Maeda, Jose Rodriguez, Marc Rich 2010. "Oh, you speak English so well!". U.S. American listeners' perceptions of "foreignness" among nonnative speakers. - Journal of Asian American Studies 13 (1), 59-79. http://dx.doi.org/10.1353/jaas.0.0062

Chenoweth, N. Ann, John R. Hayes 2001. Fluency in writing: Generating text in L1 and L2. - Written Communication 18 (1), 80-98. http://dx.doi.org/10.1 177/0741088301018001004

Ellis, Rod, Gary Barkhuizen 2005. Analysing accuracy, complexity, and fluency. R. Ellis, G. Barkhuizen (Eds.), Analysing Learner Language. Oxford: Oxford University Press, 139-164.

Eskey, David E. 2005. Reading in a second language. - E. Hinkel (Ed.), Handbook of Research in Second Language Teaching and Learning. Mahwah, NJ: Erlbaum Associates, 563-579. 
EVK 2003 = Eurooppalainen viitekehys: Kielten oppimisen, opettamisen ja arvioinnin yhteinen eurooppalainen viitekehys. Porvoo: WS Bookwell.

Fulcher, Glenn, Fred Davidson 2010. Language Testing and Assessment. London: Routledge Applied Linguistics.

Grönfors, Martti 1982. Kvalitatiiviset kenttätyömenetelmät. Helsinki: WSOY.

Hamp-Lyons, Liz 2000. Fairnesses in language testing. - A. J. Kunnan (Ed.), Fairness and Validation in Language Assessment. Selected Papers from the 19th Language Testing Colloquium Orlando, Fla. Cambridge: Cambridge University Press, 30-35.

Hassinen, Sirje 2002. Simultaaninen kaksikielisyys. Läheiset sukukielet viro ja suomi rinnakkain ['Simultaneous bilingualism. Closely related languages Estonian and Finnish side by side']. Acta Universitatis Ouluensis. B, Humaniora. Oulu: Oulun yliopisto. http://urn.fi/urn:isbn:951426648X

Huhta, Ari, Sauli Takala 1999. Kielitaidon arviointi. - K. Sajavaara, A. PiirainenMarsh (Toim.), Kielenoppimisen kysymyksiä. Jyväskylä: Jyväskylän yliopistopaino, 179-228.

Kaivapalu, Annekatrin 2005. Lähdekieli kielenoppimisen apuna ['Contribution L1 to foreign language acquisition']. Jyväskylä studies in humanities 44. Jyväskylä: Jyväskylän yliopisto. http://urn.fi/URN:ISBN:951-39-2391-6

Kaivapalu, Annekatrin 2009. Vironkielisen suomenoppijan äidinkieli - ongelma, haaste vai voimavara? ['Estonian as the first language of a learner of Finnish: Problem, challenge or resource?'] - Virittäjä 3, 382-401.

Lippi-Green, Rosina 1997. English with an Accent. Language, ideology, and discrimination in the United States. London: Routledge.

Martin, Maisa 1999. Suomi toisena ja vieraana kielenä ['Finnish as a second and foreign language']. - K. Sajavaara, A. Piirainen-Marsh (Toim.), Kielenoppimisen kysymyksiä. Jyväskylä: Jyväskylän yliopistopaino, 157-178.

Martin, Maisa 2006. Suomi ja viro oppijan mielessä. Näkökulmia taivutusmuotojen prosessointiin. - Annekatrin Kaivapalu, Külvi Pruuli (Toim.), Lähivertailuja 17. Jyväskylä Studies in Humanities 53. Jyväskylä: Jyväskylän yliopisto, 43-60.

Munro, Murray J., Tracey M. Derwing 1995. Foreign accent, comprehensibility and illegibility in the speech of second language learners. - Language Learning 45 (1), 73-97.

Nikula, Tarja 2000. Pragmaattinen näkökulma kieleen. - K. Sajavaara, A. Piirainen-Marsh (Toim.), Kieli, diskurssi \& yhteisö. Soveltavan kielentutkimuksen teoriaa ja käytäntöä. Jyväskylä: Soveltavan kielentutkimuksen keskus, Jyväskylän yliopisto, 331-358. 
Nissilä, Leena 2011. Viron kielen vaikutus suomen kielen verbien ja niiden rektioiden oppimiseen ['Impact of the Estonian language on the learning of Finnish verbs and their rections']. Acta Universitatis Ouluensis. B, Humaniora. Oulu: University of Oulu. http://urn.fi/urn:isbn:9789514296161

Osterman, Karen F., Robert B. Kottkamp 2004. Reflective Practice for Educators. Professional Development to Improve Student Learning. Thousand Oaks, Ca: Corwin Press.

Piske, Thorsten, Ian R. A. MacKay, James Emil Flege 2001. Factors affecting degree of foreign accent in and L2: A review. - Journal of Phonetics 29 (2), 191215. http://dx.doi.org/10.1006/jpho.2001.0134

Skutnabb-Kangas, Tove 1988. Vähemmistö, kieli ja rasismi. Helsinki: Gaudeamus.

Street, Richard L., Robert Hopper 1982. A model of speech style evaluation. E. Bouchard Ryan, H. Giles (Eds.), Attitudes towards Language Variation. Social and Applied Contexts. London: Edward Arnold.

Suni, Minna 1996. Maahanmuuttajaoppilaiden suomen kielen taito peruskoulun päättövaiheessa. Opetushallitus. Moniste 11/1996.

Tarnanen, Mirja 1998. Ymmärtämisen arvioinnin monet kasvot. - Tempus 7, $13-15$.

Tarnanen, Mirja 2014. Arvioija taidon arvottajana. - T. Leblay, T. Lammervo, M. Tarnanen (Toim.), Yleiset Kielitutkinnot 20 vuotta. Opetushallitus. Raportit ja selvitykset 16, 115-124.

Toivola, Minnaleena 2011. Vieraan aksentin arviointi ja mittaaminen Suomessa. Väitöskirja. Helsingin yliopiston käyttäytymistieteiden laitos. http://urn.fi/ URN:ISBN:978-952-10-7217-8

Tossavainen, Henna, Sari Ahola 2014. Yleisten kielitutkintojen arvioijakoulutus. T. Leblay, T. Lammervo, M. Tarnanen (Toim.), Yleiset Kielitutkinnot 20 vuotta. Opetushallitus. Raportit ja selvitykset 16, 125-134.

Tuomi, Jouni, Anneli Sarajärvi 2009. Laadullinen tutkimus ja sisällönanalyysi. Tammi.

Ullakonoja, Riikka 2011. Da. Eto Vopros! Prosodic development of Finnish students' read-aloud Russian during study in Russia. Jyväskylä Studies in Humanities 151. Jyväskylä: University of Jyväskylä. http://urn.fi/ URN:ISBN:978-951-39-4209-0

Yleisten kielitutkintojen perusteet 2011. Määräys 24/011/2011. Opetushallitus. 


\title{
Finnish raters' beliefs about assessing Estonian speakers in a Finnish language test: easy or difficult?
}

\author{
SARI AHOLA, HENNA TOSSAVAINEN \\ University of Jyväskylä
}

This paper aims to contribute to our understanding on rater beliefs and views and to promote transparency in rater's work in the form of reflection. The paper focuses on professional Finnish raters' beliefs and views of assessing L1 Estonian speakers in the criteria-referenced Finnish language test of the National Certificates of Language Proficiency test system. Finnish raters $(\mathrm{N}=27)$ were asked via email to shortly reflect on what they find easy and what difficult in rating Estonian speakers' writing and speaking skills in the Finnish language test. The raters reflected on many issues which may or may not have direct influence in their rating thus bringing about assessment issues relating to reliability and validity: rating influenced by views and beliefs outside the established CEFR-based criteria. Content analysis was used to classify and organize the answers. Rater views highlighted the closeness of Estonian and Finnish cultures and language relations, which had both positive and negative impact on their attitudes. The raters regarded this closeness as a merit in that the test tasks and instructions were often easily understandable by the candidates and that the candidates appeared to be trained to taking tests, i.e. had considerable test-taking skills compared to candidates from more distant cultures. As the two languages are closely related, there is also considerable overlap between them, hence the raters pointed out that it was at times difficult to identify whether the candidates were speaking or writing Finnish or Estonian and more importantly whether this influences and should influence their assessment or not. There was negative interference in particular in words, idioms and grammar but in general mistakes made by these candidates were often minor and did not impede understanding. An unsolved issue from the rating perspective was the fact that raters could understand the candidates even though it was not clear which of the two languages was in use. While at the same time individual mistakes were not the focus in assessment but rather understanding the candidate product, the raters wished to point out this 
fairness issue in rating the skills in a language. The raters generally considered the candidate products easy to read and listen to, thus a common assessment criterion, fluency was usually fulfilled.

Keywords: validity in language assessment, rater beliefs, Finnish as L2, Estonian

\section{Sari Ahola}

Soveltavan kielentutkimuksen keskus

PL 3540014 Jyväskylän yliopisto, Finland sari.ahola@jyu.fi

\section{Henna Tossavainen}

Soveltavan kielentutkimuksen keskus

PL 3540014 Jyväskylän yliopisto, Finland

henna.tossavainen@jyu.fi 